\title{
THE ISSUES OF THE NUMBER OF WESTERN ARMENIANS AND ETHNIC COMPOSITION OF THE POPULATION OF WESTERN ARMENIA AT PARIS PEACE CONFERENCE (1919-1920)
}

\author{
Dr. Robert Tatoyan \\ Armenian Genocide Museum-Institute Foundation, Armenia
}

References to the issues of the number of Western Armenians and the ratio of Armenians to other ethnic groups in Western Armenia on the eve of the Armenian Genocide occupy a special place in the context of processes related to drafting a peace agreement with the Ottoman Empire and Armenia's delineation after WWI. These issues were tackled by diverse Armenian official and non-official organizations struggling for the formation of an integral Armenian state, as well as Turkish authorities manipulating, inter alia, also demographic arguments against the Armenian claim for Western Armenia $^{1}$ and the Entente Powers (particularly the United States of America and Great Britain) needing statistical data for deciding the fate of the Ottoman Empire. In the post-war processes the long-distance controversy of the Armenian and Turkish sides over the issues in question can be figuratively characterized as one of the stages -"battles" of the "statistical war" that emerged after 1878, i.e. following the entry of the Armenian Question into the international diplomatic agenda.

This article aims to present and analyse the statistics on the number of Western Armenians and the ratio of Armenians in Western Armenia to other ethnic groups on the eve of the Armenian Genocide presented by Armenian and Turkish delegations at Paris Peace Conference, as well as data circulated by the US and British diplomacy. It will try to explain the connection between the delineation of Armenia and the number of Western Armenians, the demographic composition of Western Armenia on the eve of the Armenian Genocide. The calculations of the number of Western Armenians have had a certain effect on deliberations around demarcation of the border between the Republic of Armenia and the Ottoman Empire in the context of post-war world regulation.

Keywords: statistics, Western Armenians' population figure, demography of the Ottoman Empire, Paris Peace Conference, Armenian question, Armenian Genocide.

The article was submitted on 23.10.2020 and accepted for publication on 08.02.2021.

This is an extended version of the author's article published in Armenian.

How to Cite: Robert Tatoyan, "The Issues of the Number of Western Armenians and Ethnic Composition of the Population of Western Armenia at Paris Peace Conference (1919-1920)," International Journal of Armenian Genocide Studies 6, no. 1 (2021): 7-31.

\footnotetext{
1 Hereinafter, in the frameworks of this article, we generally refer the concept of "Western Armenia" to the territory of the Ottoman Empire, theoretically claimed by the Armenian diplomacy after WWI, namely the vilayets of Sivas (Sebastia), Erzeroum, Van, Bitlis (Baghesh), Diarbekir and Kharput (Kharberd, Mamuret-ul-Aziz), Cilicia (Adana, Djebel-Bereket and Kozan (Sis) sanjaks of Adana vilayet, Marash sanjak of Aleppo vilayet) and the eastern section of Trebizond vilayet.
} 


\section{Principles of Post-war World Regulations after WWI}

On 30 October 1918, the armistice concluded between the Ottoman Empire and, on behalf of Entente, the Great Britain representatives in Mudros harbour on the Greek island of Lemnos put an end to the participation of the Ottoman Empire in WWI. The afterlife of the country was to be decided at the Peace Conference convened in Paris on 18 January 1919. In this regard, the Armenian Question reappeared on the active agenda of international diplomacy, in the given period specifically expressed in the form of inclusion of Western Armenian territories in the integral Armenian state and demarcation of Armenia's western borders correspondingly.

As far back as on 8 January 1918 the US president Woodrow Wilson addressing the joint session of the US Congress and the Senate presented the principles whereon the post-war regulation of the world should be based. They went down in history as "fourteen points." Of those points the twelfth particularly referred to the Ottoman Empire: "The Turkish portions of the present Ottoman Empire should be assured a secure sovereignty, but the other nationalities which are now under Turkish rule should be assured an undoubted security of life and absolutely an unmolested opportunity of autonomous development..." As the guiding principle relating to the sovereignty over territories of the Ottoman Empire including those of Western Armenia was declared the right to "autonomous development" of the peoples living there, i.e. the right of nations to self-determination. This principle was highlighted and elaborated in Wilson's new speech delivered before the US Congress and Senate on 11 February 1918 the main provisions of which were: “...peoples... are not to be bartered about from one sovereignty to another...," "...every territorial settlement involved in this war must be made in the interest of and for the benefit of the populations concerned...," "...all well-defined national aspirations shall be accorded the utmost satisfaction...without introducing new or perpetuating old elements of discord and antagonism...",3

The US delegation to the Peace Conference managed to make the Entente allies see the above principles or "Wilson's doctrine" as a base for negotiations, including, also, with regard to the partition of the Ottoman Empire and demarcation of Armenia's western boundaries. ${ }^{4}$ This was specifically expressed in the joint statement adopted by the governments of France and Great Britain on 9 November 1918, which particularly read: "The object aimed at by France and Great Britain in prosecuting in the East the War ...is the complete and definite emancipation of the peoples so long oppressed by the Turks and the establishment of national governments and administrations deriving their authority from the initiative and free choice of the indigenous populations. ${ }_{5}$

Based on this, the issues of the number of Armenians in Western Armenian districts and their ratio to Muslim - Turkish and Kurdish - population on the eve of the Armenian Geno-

2 Paul C. Helmreich, From Paris to Sèvres: The Partition of the Ottoman Empire at the Peace Conference of 1919-1920 (Columbus: Ohio State University Press, 1974), 8.

3 Ibid.

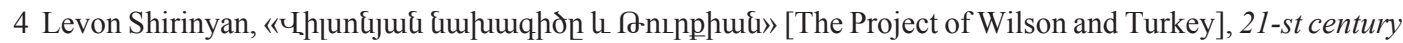
4 (2008): 100.

5 United States Department of State, Papers Relating to the Foreign Relations of the United States, The Paris Peace Conference, 1919, Volume V (U.S. Government Printing Office, 1946), 3. 
cide gained importance and were referred to in the context of negotiation of the conditions of peace with the Ottoman Empire.

At the same time, it should be noted that though important, the demographic factor was not key in deciding the fate of the Ottoman Empire. In tackling the issue of sovereignty over the territories of the Ottoman Empire, including those of Armenians, the Entente Powers adopted as a guiding principle not only the existing demographic situation in those territories and the right of "nations to self-determination," but also malfeasances committed by Turkey against its subject peoples, and in case of Armenia, the "terrible massacres." In particular, a memorandum prepared by the British Foreign Office (circulated on 21 November 1918) read:

It would be expedient to extend the area of Armenia as widely as possible, so as to include all territories north of the boundary in which there is mixed population of Turks, Armenians and Kurds... The principle of equality for all elements in the population is not disputed. On the other hand, in settling the proportional claims of these various elements to a voice in the government of the country, it should be laid down in Armenia that the dead and exiles should be taken into account, and Armenian immigrants from other parts of the world into Armenia should be given the same facilities as Jewish immigrants into Palestine for settling down in their ancestral home. ${ }^{6}$

The principle of substantiation of the right of the Armenians to the territory of Western Armenia with the fact of the crimes committed by the Turkish authorities was recapitulated in Clause 2 of the Resolution adopted during the 30 January 1919 session of the Council of Ten ${ }^{7}$ within the framework of the Paris Peace Conference: “...because of the historical misgovernment by the Turks of subject peoples and the terrible massacres of Armenians and others in recent years, the Allied and Associated Powers are agreed that Armenia, Syria, Mesopotamia, Palestine and Arabia must be completely severed from the Turkish Empire..." 8

\section{The Issue of the Number of Western Armenians on the Eve of the Arme- nian Genocide in the Post-war Memoranda of the Armenian Delegation}

The Armenian Delegation to the Paris Peace Conference, putting forward territorial claims to Western Armenia, first of all substantiated them with the sacrifices made by the Arme-

\footnotetext{
6 Richard G. Hovannisian, The Republic of Armenia, Vol. 1: The First Year, 1918-1919 (Berkley and Los Angeles: University of California Press, 1971), 267.

7 The Council of Ten (known also as the Supreme Council) was composed of two representatives from the five victorious Allied Powers each (Great Britain, France, USA, Italy, Japan).

8 United States Department of State, Papers Relating to the Foreign Relations of the United States, The Paris Peace Conference, 1919, Vol. III (U.S. Government Printing Office, 1943), 795. Here, it should be noted that other states, who fought within the Entente, also perceived the subordination of the Wilsonian principles relative to the Armenian Question. Thus, during the presentation of the Greek case before the Paris Peace Conference on 3 and 4 February 1919, the Prime Minister of Greece Eleutherios Venizelos, reaffirming his support for Armenians, stated that the Turkish Settlement must allow for a "broad and generous interpretation" of the Wilsonian principles, for it would otherwise be impossible to resolve the Armenian Question and "...so put a stop to the sufferings of those people who had lost through massacres over one million people during the course of the war." Hovannissian, Republic of Armenia, 273.
} 
nian people for the victory of the Entente Powers, the facts of Armenian moral and military support to the Allies. ${ }^{9}$ But concurrently, as the Wilsonian principle of "self-determination of nations" was at the heart of the conference work, the Armenian side could not but bring up the matter of the number of the Armenian population of Western Armenia and its ratio to other ethnic groups on the eve of the Armenian Genocide. This was particularly referred to in a large number of memoranda and reports brought to the attention of the Paris Peace Conference in defence of the idea of creation of an integral Armenian state by the Armenian representatives. ${ }^{10}$

The first and perhaps the most important of the mentioned documents is the memorandum entitled "The Armenian Question before the Peace Conference"11 and presented by the leaders of the Armenian Delegation Poghos Nubar and Avetis Aharonian to the session of the Supreme Council of the Paris Peace Conference on 26 February $1919 .{ }^{12}$

The beginning of the memorandum reads as follows: "On the fields of battle, through massacre and deportation, Armenia has proportionately paid in this war a heavier tribute to death than any other belligerent nation. ...her sufferings would have sufficed to justify her claim to independence, but...she has other meritorious claims of historical, ethnical, political and moral order... which are no less important. "'13

The "ethnical" rights of the Armenians are rendered in the section of the memorandum entitled "Integral Armenia" and particularly in the annexes entirely dedicated to the number of the Armenian population of Western and Eastern ${ }^{14}$ Armenia, their ratio to other ethnicities/nationalities before and after the Great War.

The authors of the memorandum stated that in examining the issue of the population of Armenia they would take into account the statistics before WWI or still earlier, before the Hamidian massacres in 1894-1896, as those killings not only took the life of 300,000 Arme-

\footnotetext{
9 Both during and after WWI the leaders of the Entente Powers were making many promises to the Armenians, assuring them that the Armenian Question will get a fair resolution. Samples of pro-Armenian statements, in particular, are collected in Vahan Cardashian, The American Committee Opposed to the Lausanne Treaty, The Lausanne Treaty, Turkey and Armenia (New York, 1926), 193-199; also A Memorandum on the Armenian Question Presented to the Council of Foreign Ministers March 7, 1947 (New York: Armenian National Council of America, 1947), 11-14.

10 For the list of memoranda and records presented by the Armenian Delegation to the Peace Conference see $A$ Catalogue of Paris Peace Conference Delegation Propaganda in the Hoover War Library (Stanford: Stanford University Press, 1926), 7, 19-22.

11 For the original in French see La question armenienne devant la conférence de la paix (Paris: Dupont, 1919). The memorandum was translated and published into Armenian (both Western and Eastern) and English: The Armenian Question before the Peace Conference. A Memorandum Presented Officially by the Representatives of Armenia to the Peace Conference at Versailles on February 26 ${ }^{\text {th }}, 1919$ (New York: Press Bureau, 1919). Armenian historiography focused on territorial claims contained in memorandum without detailed analysis

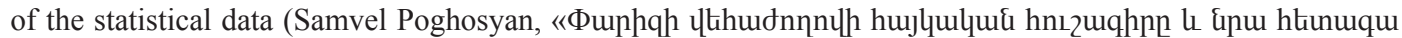
Gulquinuqhnр» [Armenian Memorandum of the Paris Conference and its Afterlife], The Issues of the History and Historiography of the Armenian Genocide 6 (2002):119-129; Hovannissian, Republic of Armenia, 277-283;

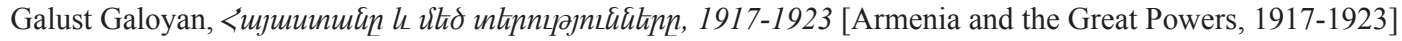
(Yerevan: Gitutyun, 1999), 102-103).

12 For the minutes of the session see: United States Department of State, Papers Relating to the Foreign Relations of the United States, The Paris Peace Conference, 1919, Vol. IV (U.S. Government Printing Office, 1943), 138-157.

13 The Armenian Question before the Peace Conference, 4.

14 Historical Armenian territory under the rule of the former Russian Empire.
} 
nians but also caused the migration of a considerable portion of the population. "The Turks' hideous deeds, which purposed to secure numerical superiority for the Moslem elements, must not be allowed to attain their end. The voice of all the Armenians, dead or alive, must be heard (bold face in the original - R.T.)." ${ }^{15}$

The authors of the memorandum acknowledged that on the eve of the Armenian Genocide the Armenians did not constitute the absolute majority over the "plurality of population" in Western Armenia, but they had a number superior to each of the Muslim nationalities taken separately: "Notwithstanding emigrations and massacres, before the outbreak of the Great War, the Armenians in the six vilayets, in the vilayet of Trebizond and Cilicia had a number superior to those of the Turks and the Kurds taken separately, and their number was equal to those of the Turks and Kurds combined. In 1914, there were in Armenia 1,403,000 Armenians, against 943,000 Turks and 482,000 Kurds, " said the memorandum. ${ }^{16}$ It should be noted, that this statement of the authors of the memorandum should be accepted with some reservation: Armenian organizations pursuing the solution of the Armenian question themselves have repeatedly been stating that the Armenians constituted the minority in the vilayet of Trebizond, as well as some peripheral regions/districts of the six vilayets (southern regions of Hakkiari, Sgherd, Diarbekir and Malatya districts and western and north-western regions of Sivas (Sebastia) vilayet, adding that those regions were annexed to the core Armenian-populated territories by the Ottoman authorities artificially to reduce the share of the Armenians. ${ }^{17}$

In the section of memorandum, entitled "The Population of Armenia," the authors put forward the following question: "What was the number of the population of Armenia prior to the massacres [i.e. the Armenian Genocide - R.T.] and what were the proportions among the various elements?" Immediately afterwards it was stated that one should never give "the slightest attention" to the Turkish data on these subjects, for the Ottoman Government had always falsified the statistics to prove that the Armenians constituted a mere insignificant minority. ${ }^{18}$ In justification of the above statement, the authors were bringing some interesting instances of "falsifications" as follows:

1. According to the Ottoman statistics, the number of the Armenian population in the vilayet of Van was around 80,000, while over 220,000 Armenians from Van had found refuge in Russia during the Great War.

2. In the entire sanjak of Marash, according to the Turkish Government's data, lived 4,200 Armenians, ${ }^{19}$ whereas according to the French geographer and traveller Elisee

15 Ibid, 7.

16 Ibid.

17 See particularly the Armenian Reform plan with its justifications presented to the attention of the Great Powers by the Patriarchate of Constantinople on reopening of the Armenian question in 1912. National Archives of Armenia, fund 57, inventory 5, dossier 15, 110-118.

18 The Armenian Question before the Peace Conference, 21.

19 This figure is taken from the French statistician Vital Cuinet's "Asiatic Turkey" book published in 1891, according to which the number of the Armenians in Marash province was 4,313 (Vital Cuinet, La Turquie d'Asie, V. 2 (Paris: Ernest Leroux, 1891), 227). It should be noted, that presenting Cuinet's data as those of the Ottoman Government by the authors of the memorandum cannot be viewed as a mistake, as Cuinet has taken the official Ottoman data as the basis for his statistics. Besides, there were no other official data on the number of the Western Armenians circulated by the Ottoman Government at the time of writing the memorandum (February 1919). 
Reclus, there were over 20,000 Armenians in the city of Marash alone. And Zeitun included in the composition of the same sanjak of Marash had 27,640 Armenians as per the statistics of the year of 1880 .

3. The Ottoman Government counted a total of 848,000 Armenians in the vilayets of Van, Bitlis, Diarbekir, Kharput, Erzeroum, Trebizond, Sivas, Adana and Aleppo, ${ }^{20}$ whereas according to the data published by the American Committee for Armenian and Syrian Relief operating in the USA in 1916 around 600,000-850,000 Armenians were killed in Armenia, the number of Armenians deported was 486,000, the number of Armenians deported to the interior of Asia Minor was 300,000, the number of those who have found refuge in the Caucasus was 200,000. ${ }^{21}$

Then the authors of the memorandum presented the two main elements of the system introduced by the Turkish Government to distort the statistics on the number of Western Armenians:

1. Reducing as much as possible the number of the Christians (including as well the Armenians) without materially modifying the number of total population and adding the difference to the number of the Muslims;

2. Avoiding to give the exact number of the nationalities, instead grouping them by religions offering separate figures for the Orthodox, Protestant and Catholic Armenians while uniting the Muslims under one figure (Turks, Tartars, Turkomans, various Kurdish tribes, Circassians, Zazas, Arabs, Persians, etc.), though "they are totally different from them [Turks] by race, their history, mode of living, degree of culture and particularly political bent." 22

In support of the arguments of the Armenian side presented in the memorandum, there were five statistical tables inserted in the Annex. Purely related to the number of Western Armenians were the two of them: "Table №1: Index of the Population of the six [Western Armenian] vilayets in 1912" and “Table №2: Population of the seven vilayets and of Cilicia in 1914." Analysis of the data contained in those tables shows that they are based on the data $^{23}$ of the Security Committee established affiliated to the Armenian Patriarchate already at the end of 1912 in connection with the reopening of the Armenian question: particularly the first table (see Table 1) was taken from the Reform plan prepared by the Security Committee without alteration.

The Ottoman Government released the official Ottoman statistical data for 1914 much later, on 14 April 1919 (Meir Zamir, "Population Statistics of the Ottoman Empire in 1914 and 1919," Middle Eastern Studies 17, no. 1 (1981): 88). According to those data in 1914 the number of the Armenian population in the sanjak of Marash was 38,433 (again lower than the real figure) (Kemal Karpat, Ottoman Population, 1830-1914: Demographic and Social Characteristics (Madison, Wisconsin: University of Wisconsin Press, 1985), 188; see also Zamir, "Population Statistics of the Ottoman Empire," 100).

20 The source of these data is also Cuinet's "Asiatic Turkey" book.

21 The Armenian Question before the Peace Conference, 21.

22 Ibid.

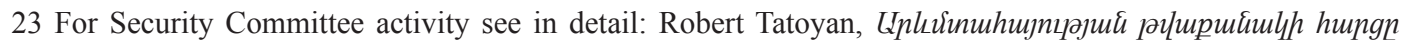
1878-1914 prulquikithu [The Question of the Number of the Western Armenians in 1878-1914] (Yerevan: AGMI, 2015), 92-94. 
Table 1. Index of the Population of the Six Vilayets in $1912^{24}$

\begin{tabular}{|c|c|c|c|c|c|c|c|c|}
\hline & $\begin{array}{l}\text { Erzer- } \\
\text { oum }\end{array}$ & Van & Bitlis & Kharput & $\begin{array}{l}\text { Diar- } \\
\text { bekir }\end{array}$ & Sivas & Total & $\begin{array}{l}\text { Per reli- } \\
\text { gion }\end{array}$ \\
\hline \multicolumn{9}{|l|}{ Moslems } \\
\hline Turks & 240,000 & 47,000 & 40,000 & 102,000 & 45,000 & 192,000 & 666,000 & \\
\hline Circassians & 7,000 & - & 10,000 & - & - & 45,000 & 62,000 & \\
\hline Persians & 13,000 & - & - & - & - & - & 13,000 & $1,178,000$ \\
\hline Lazes & 10,000 & - & - & - & - & - & 10,000 & \\
\hline Gypsies & - & 3,000 & - & - & - & - & 3,000 & \\
\hline Kurds sedentary & 35,000 & 32,000 & 35,000 & 75,000 & 30,000 & 35,000 & 242,000 & \\
\hline --- nomadic & 40,000 & 40,000 & 42,000 & 20,000 & 25,000 & 15,000 & 182,000 & \\
\hline \multicolumn{9}{|l|}{ Christians } \\
\hline Armenians & 215,000 & 185,000 & 180,000 & 168,000 & 105,000 & 165,000 & $1,018,000$ & \\
\hline Nestorians & & & & & & & & $1,183,000$ \\
\hline $\begin{array}{c}\text { Jacobites Chal- } \\
\text { deans }\end{array}$ & - & 18,000 & 15,000 & 5,000 & 60,000 & 25,000 & 123,000 & \\
\hline Greeks & 12,000 & - & - & - & - & 30,000 & 42,000 & \\
\hline \multicolumn{9}{|l|}{ Other religions } \\
\hline Kizilbashis & 25,000 & - & 8,000 & 80,000 & 27,000 & - & 140,000 & 254,000 \\
\hline Zaza Tchareklis & 30,000 & - & 47,000 & - & - & - & 77,000 & \\
\hline \multirow[t]{2}{*}{ Yezidis } & 3,000 & 25,000 & 5,000 & - & 4,000 & - & 37,000 & \\
\hline & 630,000 & 350,000 & 382,000 & 450,000 & 296,000 & 507,000 & Grand total & $2,615,000$ \\
\hline
\end{tabular}

Much interesting is the second table of the memorandum entitled "Population of the seven vilayets ${ }^{25}$ and of Cilicia in 1914," most probably prepared by the authors of the annexes to the memorandum themselves (see Table 2). For the first time the 2,026,000 figure standing for the total number of the Armenian population of the Ottoman Empire as of 1914 was put into circulation (see Table 2). ${ }^{26}$ Previously the 1912 statistical data of the Armenian Patriarchate of Constantinople were used by the renowned Western Armenian figure Grigor Zohrap under the pseudonym Marcel Leart in his work "The Armenian Question in the Light of Documents" published in 1913 in French. ${ }^{27}$ As calculated by Zohrap, there were 2,100,000 Armenians living in the entire Ottoman Empire in 1912. ${ }^{28}$

24 Exclusive of the regions of Hakkiari, those situate to the south of Seghert, of Diarbekir, of Malatia, to the west and north-west of Sivas.

25 The six vilayets of Western Armenia completely, plus the sanjak of Trebizond of the Trebizond vilayet.

26 The statistics in its complete form, including data for all administrative (vilayet) units of the Ottoman Empire,

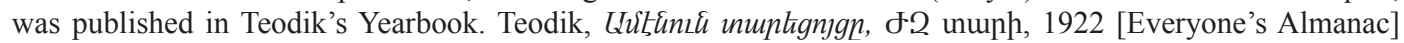
(Constantinople, 1921), 261-263.

27 See Leart Marcel, La question Armenienne a la lumiere des documents (Paris: Challamel, 1913).

28 Ibid, 62. In Zohrap's book the figure for the Armenian population of the six vilayets of Western Armenia 
Table 2. Population of the Seven Vilayets and of Cilicia in 1914

\begin{tabular}{|c|c|c|c|c|}
\hline & $\begin{array}{l}\text { The } 7 \text { vilayets } \\
\text { Exclusive of the } \\
\text { regions situated } \\
\text { to the south of } \\
\text { the Tigris and to } \\
\text { the west of Ye- } \\
\text { shil-Irmak }\end{array}$ & $\begin{array}{c}\text { Cilicia } \\
\text { Sanjaks of Adana, of } \\
\text { Marash, of Kozan } \\
\text { and of Djebel-Bere- } \\
\text { ket }^{29}\end{array}$ & Total & \\
\hline Armenians & $1,198,000$ & 205,000 & $1,403,000$ & \multirow{3}{*}{$\begin{array}{l}1,850,000 \\
\text { Christians }\end{array}$} \\
\hline Greeks & 242,000 & 40,000 & 282,000 & \\
\hline $\begin{array}{l}\text { Nestorians Jaco- } \\
\text { bites, Chaldeans and } \\
\text { Europeans }\end{array}$ & 124,000 & 41,000 & 165,000 & \\
\hline Turks and Turkmens & 865,000 & 78,000 & 943,000 & \multirow[b]{2}{*}{$1,635,000$} \\
\hline Kurds & 424,000 & 58,000 & 482,000 & \\
\hline $\begin{array}{l}\text { Lazez, Circassians, } \\
\text { Arabs, Persians }\end{array}$ & 190,000 & 20,000 & 210,000 & Mussulmans \\
\hline \multirow[t]{2}{*}{$\begin{array}{l}\text { Kizilbashis, Yezidis, } \\
\text { Fellahs, etc }\end{array}$} & 255,000 & 48,000 & 303,000 & \multirow[t]{2}{*}{$\begin{array}{l}303,000 \\
\text { diverse reli- } \\
\text { gions }\end{array}$} \\
\hline & $3,298,000$ & 490,000 & $3,788,000$ & \\
\hline \multicolumn{5}{|c|}{ Total Armenian Population in Turkey in 1914} \\
\hline In Turkish Armenia ${ }^{30}$ & & (.). & \multicolumn{2}{|c|}{$1,403,000$} \\
\hline In other parts of Asiatic & urkey & (n) & \multicolumn{2}{|c|}{440,000} \\
\hline In Constantinople and $\mathrm{H}$ & ropean Turkey & & \multicolumn{2}{|c|}{183,000} \\
\hline Total & & & \multicolumn{2}{|c|}{ 2,026,000 Armenians } \\
\hline
\end{tabular}

is the same 1,163,000 people, then for the rest of the Ottoman Empire it says 937,000 Armenians, of which 407,000 in Cilicia, 530,000 in other regions of the Ottoman Empire and European Turkey. For comparison: the version of 1912 statistics of the Armenian Patriarchate of Constantinople published in Teodik's Almanac for the same regions gives the figure of 863,700 Armenians, including 304,000 Armenians in Cilicia (Adana and Aleppo vilayets). Apparently, the decrease in the number of the Armenian population from 2,100,000 to 2,026,000 in 1914 compared to the year of 1912 is explained by the territorial losses of the Ottoman Empire due to the Balkan wars in 1912-1913, while in case of Cilicia, by the divergence of the Ottoman administrative and Armenian diocesan division (under the jurisdiction of the Armenian Catholicosate of Cilicia were territories outside the core historical and geographic areas of Cilicia in the territories of the vilayets of Angora, Sebastia and Kharput the number of the Armenian population of which Zohrap had calculated in the total number of the population of Cilicia).

29 The authors of the memorandum included in Cilicia the following Ottoman administrative units: entire Adana vilayet, the sanjak of Marash (Marash, Zeitun, Furnuz) and the district of Alexandrette of the sanjak of Aleppo of the Aleppo vilayet.

30 Six Armenian vilayets, the province of Trebizond and the sanjaks of Cilicia, Adana, Marash, Kozan and Djebel-Bereket. 
In other memoranda and reports published by the Armenian Delegation on various occasions later the statistical data and tables on the number of the Western Armenians on the eve of the Armenian Genocide were essentially the reprints of the data of the memorandum of 12 February $1919 .{ }^{31}$

The Armenian Patriarchate of Constantinople was also engaged in the collection and recapitulation of various evidence including statistical data on the status of the Western Armenians on the eve of the Armenian Genocide concurrently and collaboratively with Armenian National Delegation. In November-December of 1918, the National League and then National Consultative Council organizations were created with participation of the Armenian intellectuals and former members of the National Assembly of Armenians in Constantinople, counting among their members Yeghishe Archbishop Durian, Professor Abraham Ter-Hakobian, Dr. Vahram Torgomian and others. ${ }^{32}$ The Documents Committee of the National Consultative Council was also performing efforts to collect data on the number of the Western Armenians on the eve of the Armenian Genocide. A portion of the materials collected was published in 1919 by Constantinople Armenian intellectual figures Chituni (Tigran Chitchian) ${ }^{33}$ and Gevorg Mesrop (Gevorg Ter-Mesropian). ${ }^{34}$

In August 1919 the Armenian Patriarchate of Constantinople established an Information

31 See particularly Tableau approximatif des réparations et indemnités pour les dommages subis par la nation arménienne en Arménie de Turquie et dans la République Arménienne du Caucase (Paris, 1919) (presented to the Paris Peace Conference on 6 April 1919), Population Armenienne de la Turquie avant la guerre. Statisitques etablies par le Patriarcat Armenienne de Costantinople (Paris: Turabian, 1920), Poghos Nubar, The Pre-War Population of Cilicia (Paris, 1920), records prepared by the Armenian Delegation for the London Conference on 12-24 February 1920 (National Archives of Armenia, fund 430, inventory 1, dossier 1325, 1-56), L'Armenie et La Question Armenienne avant, pedant et depuis la guerre (Paris, 1922), the memorandum presented by the Armenian Delegation to the Lausanne Conference in 1923 (National Archives of Armenia, fund 430, inventory 1, dossier 1358, 3-32). Along with the abovementioned memoranda and reports/statements, the Armenian Delegation in 1918-19 published and presented to the delegations of the Entente Powers 23 fascicles of Armenian and foreign authors relating to various aspects of the Armenian Question, in some of which there was a reference to the number of the Western Armenians (for the list of the fascicles see National Archives of Armenia, fund 430, inventory 1, dossier 167, 9-10). It is noteworthy that a statesman of the first Republic of Armenia Alexander Khatisian in his book reported that in one of the writings presented by the All Armenian Delegation to the delegates of the Lausanne Conference in 1923 the number of the Armenian population of the Ottoman Empire on the

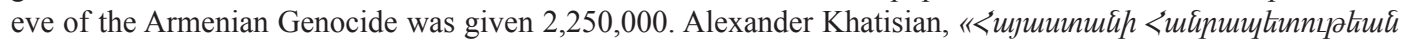

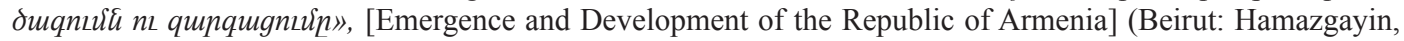
1968), 365. We believe that this figure is closer to reality, however, unfortunately Khatisian did not mention any other detail in connection with it (the source of the figure, distribution by provinces, etc.). Also, this figure has not been quoted in the memoranda presented to the Lausanne Conference by the Armenian Delegation. During our searches in the fund of the All Armenian Delegation of the National Archives of Armenia (National Archives of Armenia, fund 430) we could not find any document relating to the figure mentioned by Khatisian.

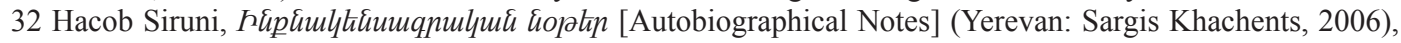
206-207:

33 Chituni, <nı2hlp <ujuminuরih [Memories of Armenia] (Constantinople, 1919); Chituni, Lu $n\llcorner\not h u<u$ јщитиицh [Conversation about Armenia] (Constantinople, 1920). Chituni, comparing several statistical sources, was probably the first among Armenian researchers to come to the conclusion that prior to 1915 the number of the Armenian population of the Ottoman Empire comprised around 2,500,000, of which 200,000 - in European Turkey, 800,000 - in Asia Minor and Palestinian and Mesopotamian vilayets, and 1,500,000 - in the six Armenian-populated vilayets and Cilicia.

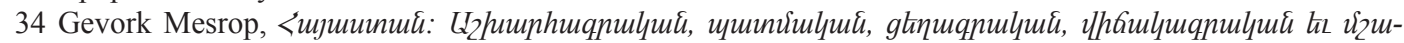

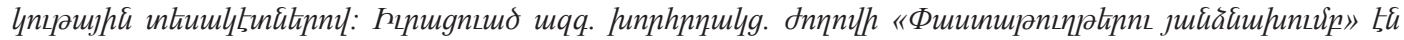
[Armenia. From the Point of View of Geography, History, Ethnology, Statistics, and Culture] (Constantinople, 1919). 
Bureau, the coordination of the work of which was entrusted to well-known Armenian intellectual figure Arshak Alpoyachian. ${ }^{35}$ According to the Charter of the Information Bureau, it was to host "old and new, all types of statistics on Armenia and the Armenian Cause... all episodes and stories about Armenian persecutions, massacres, deportation, statistical images of stolen national and individual movable and immovable property... "36 The report prepared by the Information Bureau on 29 June 1920 stated that the agency "has initiated preparation of a collection, which will illustrate the real state of the dioceses of the Patriarchate at the dawn of the [First World] War, that is the number of churches, monasteries, schools, national properties and population of each primacy. "37 The Documentation Collection and Repository section of the report said that the Bureau "...collects and arranges... all beneficial documents about Armenian social and political life. Hence, over 600 reports, statistics, etc. published by Armenian societies or official bodies."

In the same year of 1919, Teodik, a Western Armenian intellectual, while collecting materials about the clergy killed during the Armenian Genocide was searching the archives of the Patriarchate and came across sacks of papers in the basements. Those were the statistical questionnaires the Armenian dioceses of the Ottoman Empire completed and sent to the Patriarchate, as instructed, on the eve of the Great War, hidden in the basement immediately after the 24 April 1915 arrests along with other documents related to the Armenian Question. ${ }^{38}$ The data extracted from those questionnaires were partially put into circulation by Teodik in his book "The Calvary of Armenian Clergy and its Flock in Catastrophic Year of 1915" published in 1921. These statistics were passed on to the Information Bureau and forwarded to the Armenian National Delegation in Paris later. ${ }^{39}$

Meanwhile the present and former Ottoman officials were trying to contradict the memorandum presented by the Armenian National Delegation and particularly the statistical data contained therein. Thus, to "prove" the invalidity of the statistical data presented by the Armenian Delegation and allege that the Armenians were a minority in Western Armenia, Reşit Safvet Atabinen, a former Young Turk state official who took refuge in Switzerland, in his booklet entitled "Turks and Armenians in the face of history. New Russian and Turkish testimonies about Armenian Atrocities. Refutation of Armenian Delegation 's Memorandum" published in May 1919 (under the pen name Kara Schemsi) ${ }^{40}$ resorted to a device that later was used by the official Turkish historiography multiple times, i.e. to show that

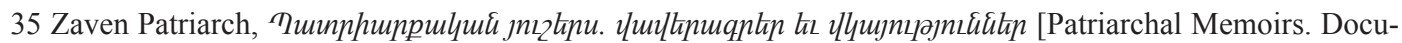
ments and Testimonies] (Cairo, 2014), 367.

36 Ibid., 368.

37 Ibid., 369.

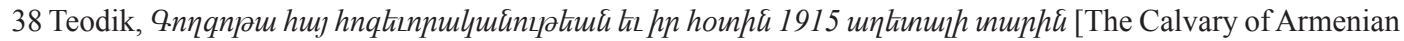
Clergy and its Flock in Catastrophic Year of 1915] (New York, 1985), III.

39 Currently the Armenian Patriarchate's 1913-14 census questionnaires are kept in Nubarian Library in Paris. They were widely used also by the Diaspora researcher Raymond H. Kevorkian, who in the expansive work co-authored with Paul Paboudjian gives the picture of the number of Armenian population in the Ottoman Empire based on the census data locality by locality. See Raymond H. Kévorkian and Paul B. Paboudjian, Les Arméniens dans l'Empire ottoman à la veille du génocide (Paris: ARHIS, 1992). For the Armenian Patriarchate 1913-14 census see also Tatoyan, The Question of the Number of the Western Armenians in 1878-1914, 92-115. 40 Kara Schemsi, Turcs et Arméniens devant l'histoire. Nouveaux témoignages russes et turcs sur les atrocités arméniennes de 1914 à 1918 (Geneve: Impr. Nat., 1919). 
the statistics of the Armenian sources are refuted not only by Turkish but also by different Western sources supposedly independent of the Turkish ones.

The author refers to two French sources containing information about the number of the Western Armenians - the Yellow Book ${ }^{41}$ statistics $^{42}$ published by the Ministry of Foreign Affairs of France in 1897 and the data in the Asiatic Turkey book of the French statistician Vital Cuinet. ${ }^{43}$ The comparison of the data available in the two sources shows that Cuinet's book has served as a source for the Yellow Book data ${ }^{44}$ of the French Ministry of Foreign Affairs: to conceal this fact Schemsi employs the following trick - he cites only the figure for the percentage of the Armenians in the six Western Armenia vilayets from the Yellow Book and then takes the numbers of the Armenians and the Muslims of the six vilayets from Vital Cuinet. The author in any way does not mention the well-known fact that Vital Cuinet's data do not possess a value of their own - they are based on the Ottoman data mostly taken from the salnames (Ottoman yearbooks, published by central and provincial authorities) and other official sources. ${ }^{45}$

Noteworthy is Schemsi's selective attitude towards the data extracted from the Yellow Book and generally from Western sources. Thus, he circumvents the figure in the Yellow Book 1,475,011 standing for the number of Armenians living in Anatolia (Asia Minor and Western Armenia without Constantinople and European Turkey) at the end of the XIX century. ${ }^{46}$ It would be understandable, if we take into account that as per the Ottoman data relating to the year of 1914 the number of the Armenian population of the entire Empire did not exceed 1,300,000.

The next source referred to by Schemsi were the figures standing for the number of the population of Van and Bitlis vilayets reported by Vladimir Mayevski, who was the Russian Vice-Consul in Van in 1890. These were also presented by the author selectively - only the percentage of Armenians vs. Muslims: 26\% for Armenians in Van, 46\% for Kurds and Turks, likewise 39\% for Armenians in Bitlis, 55\% ${ }^{47}$ for Kurds and Turks. The purpose of the Turk official becomes clear when we read through V. Mayevski's numbers, according to which there were 13,735 and 23,326 Armenian households ${ }^{48}$ in Van vilayet and Bitlis vilayet respectively. Mayevski assumed an average number of 8 members of families, which in

\footnotetext{
41 Yellow Books (livres jaunes) were called the fascicles of the collections of diplomatic documents, which the minister of foreign affairs of France presented to the country's Parliament for discussion.

42 Documents diplomatiques: affaires arméniennes; projets de reforme dans l'Empire ottoman 1893-1897 (Paris: Imprimerie nationale, 1897).

43 Here the author uses data contained in Ottoman government's official documents published earlier in 1919, which we will examine in the following section of the article.

44 More details about this to follow.

45 For substantial examination of Vital Cuinet's data see Haykazun Galstyan, «Unluưnjuú <ujuuunuûh

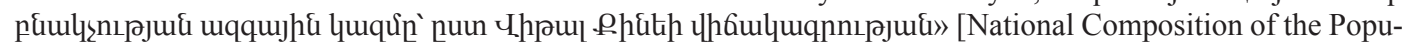
lation in Western Armenia according to Vital Cuinet's Statistics], Countries and Peoples of the Near and Middle East, XII, Turkey (1985): 59-79; Sarkis Y. Karayan, "Vital Cuinet's La Turquie d'Asie: A Critical Evaluation of Cuinet's Information about Armenians," Journal of the Society for Armenian Studies, 11 (2000): 53-63.

46 See Documents diplomatiques: affaires arméniennes; projets de reforme dans l'Empire ottoman 1893-1897, 8. 47 Schemsi, Turcs et Arméniens, 119.

48 Сборникъ дипломатическихъ документовъ. Реформы въ Арменіи (26 ноября 1912 г. - 10 мая 1914 г.) [Collection of Diplomatic Documents. Reforms in Armenia (1912, November 26 - 1914, May 10)] (Petrograd, 1915), 284, 288.
} 
case of Van vilayet would amount to 109,880 Armenians and for Bitlis - 186,608. For the Armenian population of the same vilayets the official Ottoman data for the year of 1914 were 67,792 and 119,132 persons respectively. ${ }^{49}$ That is to say, for the number of the Armenian population Mayevski's data, which he, like Cuinet, had taken from local Ottoman yearbooks, were about $40 \%$ higher compared to the statistics of the Ottoman Government. ${ }^{50}$

\section{The Issue of the Number of Western Armenians in the Post-war Memo- randa of the Ottoman Government}

After the defeat in WWI the new Ottoman government continued to advance and develop the traditional line of the regimes of Abdul Hamid and Young Turks in the Armenian Question, i.e. to declare that the Armenians were an insignificant minority in "Eastern Anatolia" even before WWI and that the Muslims had been the predominant ethnic and religious element there for centuries. ${ }^{51}$ In 1919-1920 both official and non-official Turkish circles published a host of memoranda and reports/pamphlets addressed to the participants in the Paris Peace Conference promoting the idea of preserving the integrity of the Turkish Empire. ${ }^{52}$ The first and perhaps the most important of such documents on the stand of the Ottoman government on the Armenian Question was the memorandum dated 12 February 1919 and addressed to the High Commissioners Representing the Entente Powers in the Constantinople. ${ }^{53}$

About the quarter of the text of the memorandum (12 pages) was dedicated to the substantiation of the notion of the Greeks and Armenians being an insignificant minority in Asia Minor and Western Armenia. Dividing the territory of the Ottoman Empire into two parts as per the "Wilsonian principles" - "Turkish" and "Arabic" provinces and declaring as Turkish the vilayets of Eastern Thrace, Asia Minor (Anatolia) and Western Armenia, the authors of the memorandum were detaching "Eastern" or "Armenian" vilayets from them in order to examine them separately. ${ }^{54}$

Introducing the names of the territorial administrative units of Eastern Thrace and Asia Minor, the authors of the memorandum claimed that the Turkish element was enjoying an overwhelming predominance in all those vilayets as stated by official statistics, as well as

49 Karpat, Ottoman Population, 188.

50 In fact, Mayevski, while examining Cuinet's data about Van vilayet, noted that they contained significant inaccuracies. Particularly, finding that the number of the Armenian population of Van district reported by Cuinet is lower than in reality the author supposed, that it concerned only the village population of the district, while together with the city of Van (13,500, according to Cuinet) the number of the Armenians should be 26,000. See Vladimir Mayevski, Ванскій вилайетъ. Военно-статистичское описаніе [Van Vilayet. Military-Statistical Description] (Tiflis, 1901), 89-90. Going on with the examination of Cuinet's data, the researcher also questioned the statistics of Van (13,500 Armenians). Based on his own observations, which according to him were confirmed even by Turkish official data, Mayevski believed that the number of the Armenian population of the city comprised 20-25 thousand (Mayevski, Van Vilayet, 100-101).

51 Hovanissian, The Republic of Armenia, 421.

52 Besides Kara Schemsi's book already referred to, see also Les Turcs Et Les Revendications Arméniennes (Paris: L'Hoir, 1919), The National Congress of Turkey, The Turco-Armenian Question. The Turkish Point of View (Societe Anonyme de Papeterie et d'Limprimerie, 1919).

53 Memorandum of the Sublime Porte Communicated to the American, British, French and Italian High Commissioners on the $12^{\text {th }}$ February 1919 (Constantinople: Zelligh Bros., 1919).

54 Ibid., 4. 
data of foreign researchers of Turkey before the War. ${ }^{55}$ This was blatant misinformation as the Kurds had a bigger number among the Muslim population compared to the Turks particularly in Van, Bitlis, Diarbekir and Kharput vilayets of Western Armenia.

In confirmation of the above statement, three sources were presented: official Ottoman data reflecting the 1914 situation, those of French statistician Vital Cuinet (early 1890-s) and data extracted from the Yellow Book (1897). The data of the last two sources almost did not vary from each other, because when compiling the Yellow Book the French Government had taken and placed Cuinet's data there without any material changes, however, the authors of the Turkish memorandum did not mention it by any means. As we already said, Cuinet's information in its turn was based on the same official Ottoman statistics, so the authors of the memorandum essentially were confirming the authenticity of the Ottoman information through the same Ottoman data offered under a different name.

The same trick was used also in case of the six Western Armenian vilayets (Van, Bitlis, Kharput, Diarbekir, Erzeroum, Sivas): at first the official Ottoman data was presented and then the statistical data taken from the Yellow book (see below) ${ }^{56}$ :

\section{Official Ottoman Statistics of the Six Vilayets}

$\begin{array}{ccc} & \text { Number of population } & \text { Proportion } \\ \text { Muslims } & 3,040,891 & 79 \% \\ \text { Armenians } & 636,306 & 16.5 \% \\ \text { Other } & 162,352 & 4.5 \%\end{array}$

\section{Yellow Book Statistics}

$\begin{array}{ccc} & \text { Number of population } & \text { Proportion } \\ \text { Muslims } & 2,669,386 & 73.5 \% \\ \text { Armenians } & 666,435 & 18.5 \% \\ \text { Other } & 272,581 & 7.5 \%\end{array}$

To fight back the Armenian claims, the authors of the memorandum felt the need of involving another Western source - Britannica Encyclopaedia (1910 edition), inserting data extracted from it. According to the Encyclopaedia, "the Armenians, even if we take the most favourable assessments, comprise the majority only in 9 (7 near Van, 2 near Mush) out of the [Western Armenian 6 vilayets' - R.T.] 159 districts (kaza)." It said that in 1896 the population of the nine Turkish vilayets - Erzeroum, Van, Bitlis, Kharput, Diarbekir, Sivas, Aleppo, Adana and Trebizond amounted to approximately 6,000,000 of which:

55 Ibid., 5.

56 Ibid., 7. 


$\begin{array}{lll}\text { Armenians } & 919,875 & \text { or } 15 \% \\ \text { Other Christians } & 632,875 & \text { or } 11 \% \\ \text { Muslims } & 4,453,250 & \text { or } 74 \%\end{array}$

According to the Britannica Encyclopaedia, the number of the population in the first five vilayets (Erzeroum, Van, Bitlis, Kharput (Mamuret-ul-Aziz), Diarbekir) counting the biggest part of the Armenians was 2,642,000, of which:

$\begin{array}{lll}\text { Armenians } & 633,250 & \text { or } 24 \% \\ \text { Other Christians } & 179,875 & \text { or } 7 \% \\ \text { Muslims } & 1,828,870 & \text { or } 69 \%\end{array}$

"The above figures do not leave room for doubt, - concluded the authors of the Turkish memorandum, - that the overwhelming majority of the population of the abovementioned vilayets is made up of the Muslims, and the Armenians are an insignificant minority everywhere. " 57

The comparison of the data in the Turkish memorandum with the original text of the Britannica Encyclopaedia revealed interesting circumstances. Thus, the authors of the memorandum used the source selectively leaving out formulations non-favourable for the Turkish official stand. For instance, omitted were the statement at the very beginning of the subsection of the article that "accurate statistics cannot be obtained" about the Ottoman Turkey, as well as the original source which Britannica Encyclopaedia was referring to - the Russian General Zelyoni's data. ${ }^{58}$ The examination of Zelyoni's data proved that the Russian researcher, in his turn, had used the data of the very same Vital Cuinet, when preparing the map of distribution of the Armenian population in Turkish Armenia and Kurdistan in 1895 on the basis of the data of the latter's book "Asiatic Turkey" (1890-1894) ${ }^{59}$ In other words, the authors of the Turkish memorandum were trying to prove the validity of official Ottoman statistical data on the number of Western Armenians by means of Vital Cuinet's data which was based on the same official Ottoman data, then by the Yellow Book of the French Ministry of Foreign Affairs, which was based on Cuinet's data and finally by the statistics contained in the Britannica Encyclopaedia, which again was based on Vital Cuinet's data. By such statistical trickery an illusion was created that the official Ottoman statistical data was corroborated by Western sources.

Thus, the statistical data of the Turkish Government was intended to prove that "five million" Muslim population should not be ruled by "several hundred thousand" Armenians,

57 Ibid., 8 .

58 Encyclopedia Britannica, 11th edition, vol. 2, (New York, 1910), 564.

59 Пояснительная записка генер. штаба Генераль-Лейтенанта Зеленого (сь приложеніями) к карть распредъленія армянскаго населенія въ Турецкой Армении и Курдистанъ по казамъ и данныя сочиненія V. Cuinet "la Turquie d'Asie" 1890-94 г., составленной ген. штаба Ген.-Лейт. Зеленымъ и Подполк. Сысоевымъ, 1895 [Explanatory Report Lieutenant General Zeliony (with Attachments) on Map of Distribution of the Armenian Population in Turkish Armenia and Kurdistan According to Data from V. Cuinet's "la Turquie d'Asie”], «Записки Кавказского отдъла Императорскаго Русскаго географическаго общества» [Notes of the Caucasus Department of the Imperial Russian Geographical Society, vol. XVIII] (Tiflis, 1896), 1-40. 
which, according to the authors of the memorandum, would inevitably lead to internal atrocities and bloody clashes. ${ }^{60}$ As a better solution, the Ottoman Government proposed to leave the territories of "Eastern Anatolia" under Turkish rule somewhat expanding the territory of the Republic of Armenia to resettle the survivors of "deported to Der Zor sanjak" Armenians there. ${ }^{61}$ Regarding the latest proposal, Turkey theoretically did not face big territorial losses as only about 250,000-300,000 of the deported Armenians managed to survive the end of the World War I in Syrian deserts. ${ }^{62}$

In addition to the memorandum of 12 February 1919, the Ottoman authorities brought to the attention of the Paris Peace Conference also a fascicle in French entitled Tables Representing the Number of Different Elements of Population in the Ottoman Empire as of 1 March $1330^{63}$ (14 March 1914) recapitulating the data of 1914 official Ottoman Statistics, according to which 1,294,851 Armenians were living in the Ottoman Empire prior to WWI. ${ }^{64}$

The reaction of the Armenian circles to the Turkish memorandum did not delay. In the same 1919 in Constantinople the Answer to the 12 February 1919 Memorandum of the Sublime Porte fascicle was published in French. Around a quarter of the 40-page writing was dedicated to the refuting of statistical data and demographic arguments contained in the Turkish memorandum, while the annexes - five in number, offered various statistics. ${ }^{65}$

The Armenian response elaborated on the main elements of the 1878-1914 administrative and demographic policy of the Ottoman Government intended to make the Muslims a majority, namely:

1. Re-delineation of the administrative borders of vilayets in Western Armenia and Cilicia, when mostly Muslim-populated regions were appended to Armenian-populated vilayets (for instance Hakkiari to Van vilayet, Mesopotamian regions to Diarbekir vilayet, the annexation of the Armenian-populated province of Marash, which was a natural part of Cilicia, to Aleppo province, the annexation of the Muslim-populated Ichil region to Armenian-populated Adana vilayet, etc.),

2. Placing Muslim settlers (known as "Muhajirs") migrated from the Caucasus and the Balkans in Armenian-populated regions, intimidation and ruthless exploitation of the Armenians by the newcomers (presented was data also from the official Turkish sources that 854,000 Muhajirs were moved to and resettled in the Turkish Empire during 1878-1908,

60 Ibid.

61 Ibid.

62 According to Turkish researcher Fuat Dundar's calculations - 300,000. Fuat Dundar, Crime of Numbers, The Role of Statistics in the Armenian Question (The State University of New Jersey-Rutgers: Transactions Publishers, 2010), 150-151.

63 According to Rumi calendar officially used in the Ottoman Empire in 1839-1926 along with the Islamic calendar.

64 The tables of 1919 French fascicle included the numbers of Muslims, Greeks, Armenians (aggregate number of Apostolic, Catholic and Protestant Armenians) and other elements. The data is distributed by the districts (kaza) of the Ottoman Empire (see Tableaux indiquant le nombre des divers éléments de la population dans l'Empire Ottoman au ler mars 1330 (14 mars 1914) (Constantinople, I9I9). See also Zamir, "Population Statistics of the Ottoman Empire," 89-101, Shaw Stanford J., "The Ottoman Census System and Population, 18311914," International Journal of Middle East Studies 9 (1978): 336. For more details on 1914 Ottoman statistics see Tatoyan, The Question of the Number of the Western Armenians in 1878-1914, 38-39.

65 Reponse au Memoire de la Sublime-Porte en date du 12 fevrier 1919 (Constantinople, 1919). 
noting that the flow of Muhajirs gained even a greater momentum during the Balkan Wars in 1912-14),

3. Even more preposterous publication of already falsified statistics, when the data of not only Turkic-speaking, but also of all Islamic tribes, even those neither professing Islam, not Christianity were being united under one - Muslims section, while the Armenians were divided into three groups - Apostolic Christians, Catholics and Protestants. ${ }^{66}$

Upon the presentment of the above theoretical statements a reference was made to certain statistical data in the Turkish memorandum. As one of the sources of the memorandum was Vital Cuinet, the Armenian response showed through references to his Asiatic Turkey book that the French statistician himself was openly critical of the Ottoman statistics. In particular, Vital Cuinet wrote: "There is absolutely no proper official statistics in Turkey, ... the [Turkish] authorities not only have not embraced such an interesting and useful statistical science in the country's practices, but on the contrary, as an interested party they refuse to authorize even simple studies. " 67

The authors of the fascicle also of fered some illustrations of inaccuracies and inconsistencies in Cuinet's data, concluding that they reflect the general "deplorable state of affairs" in Ottoman official data. ${ }^{68}$

\section{US Experts and post-War Missions on the Issue of the Number of West- ern Armenians}

To decide the fate of the territories of the Ottoman Empire the Allied Powers - victorious in the Great War, needed varied information and first of all demographic data relating to the territories in question. The issue was complicated by the fact that the data received from the Armenian and Ottoman circles were contradictory forcing the representatives of Western countries dealing with them to take a specific stance on the issue - reject or accept the arguments and data of one of the sides, or do own reckoning.

The issue of Armenia boundaries coupled with the number of the Western Armenians on the eve of the Armenian Genocide has particularly been in the sphere of interests of the United States of America, as it was in direct correlation with the question whether it was expedient or possible for the state to assume Armenia's mandate. Still in September of 1917, the US President Woodrow Wilson commissioned to establish a study group - The Inquiry, with an aim to collect data for the peace negotiations to follow WWI. The task of collecting information about Armenia and the Armenians was assigned to the Western Asia section of the group consisting of 10 experts. ${ }^{69}$ Upon the end of the Great War the members of the study group, including Western Asia section, integrated into the composition of the American Delegation to the Paris Peace Conference. ${ }^{70}$

66 Ibid., 14-17.

67 Ibid., 40.

68 Ibid., 18.

69 Lawrence Gelfand, The Inquiry; American Preparations for Peace, 1917-1919 (New Haven: Yale University Press, 1963), 60.

70 Richard G. Hovhannisian, "The Armenian Genocide and US post-war commissions," in Jay Winter, ed., America and the Armenian Genocide of 1915 (Cambridge: Cambridge University Press, 2003), 259. 
The archive of The Inquiry study group contains 98 documents relating to the Armenian Question, mostly reports of the members of the study group, as well as records of American missionaries. Some 13 of those documents deal with the partition of Ottoman Turkey and 11 relate to national and religious minorities. Many of the above documents deal with the issue of the number of Western Armenians in one way or another. ${ }^{71}$ The Inquiry study group has also prepared extensive reports about various, including Western Armenian, vilayets of the Ottoman Empire, containing statistical data as well. ${ }^{72}$

Of the documents prepared by The Inquiry study group dealing with the number of Western Armenians on the eve of the Armenian Genocide noteworthy is the Population of Asiatic Turkey at the Outbreak of the War report dated 15 November 1918, authored by the member of the Western Asia section professors David Magie and William Linn Westermann, circulated during the Paris Peace Conference and, in its turn, used for preparation of various reports and bulletins relating to the Armenian Question. ${ }^{73}$

To study the situation in the territories of the Ottoman Empire for the purpose of determining the US policy towards the country, in 1919 the US Government sent two commissions or missions to the region known by the names of their leaders King-Crane ${ }^{74}$ and Harbord.$^{75}$ The King-Crane mission was composed of civilians with an aim of studying the territories of the entire Ottoman Empire; Harbord mission was composed mainly of the military and its primary goal was to examine the situation in the region particularly in terms of the possibility of assuming a mandate for Armenia. These commissions compiled reports resulting from their work in which a certain place was given to the issues of the number of the Armenian population of Western Armenia and the proportion of the Armenians to the Muslims on the eve of the Armenian Genocide.

The authors of the King-Crane Mission Report ${ }^{76}$ were interested in the number of West-

\footnotetext{
71 According to the data of Diaspora Armenian researcher Armen Hovannissian: "The United States Inquiry and the Armenian Question, 1917-1919: the Archival Papers," Armenian Review 37, no. 1 (1984):148.

72 For the complete list of the documents on Turkey of The Inquiry study group see National Archives Inventory 9: Records of the American Commission to Negotiate Peace, Inventory of Record Group 256, compiled by Sandra K. Rangel, National Archives and Records Service Administration (Washington, 1974), 81-92, available online at http://www.archives.gov/research/foreign-policy/related-records/inventory9.pdf), accessed 02.06.2020. 73 For Magie's records see National Archives Inventory 9: Records of the American Commission to Negotiate Peace, Inventory of Record Group 256, 83.

74 The commission is named after its two members - theologian Henri King and US democrat figure Charles Crane. It started its work in June 1919 and prepared its report on 28 August 1919. For more details about the King-Crane commission, see James B. Gidney, A Mandate for Armenia (Kent, Ohio: Kent State University Press, 1967), 136-167.

75 The Harbord military mission consisting of over 50 people was led by General James Harbord of the US Army. He was tasked to "explore and report about the political, military, geographical, administrative, economic and other conditions of the regions that could be of interest to the USA..." The mission visited Turkey (the provinces of Cilicia, Diarbekir, Sebastia, Kharput, Erzeroum), the first Republic of Armenia, as well as Tiflis, Baku, Batum. The outcomes of the mission were summed up in the Middle East Situation report presented to the US President on 23 October 1919 and submitted to the US Congress for discussion in April of 1920 (see Hovhannisian, "The Armenian Genocide," 265. For the references of Armenian historiography to the activity of

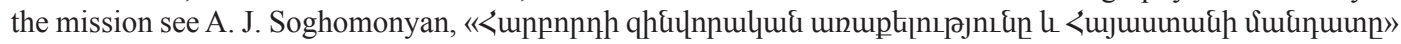
[Harbord's military Mission and the Armenian Mandate], The Herald of Social Sciences 9 (1985): 13-23).

76 For the complete King-Crane Report see United States Department of State, Papers Relating to the Foreign Relations of the United States, The Paris Peace Conference, 1919, Vol. XII (U.S. Government Printing Office, 1947), 751- 863.
} 
ern Armenians on the eve of the Armenian Genocide with a view to create a "separate Armenia." Upon outlining the grounds for creation of an Armenian state on some of the territories cut off from the Ottoman Empire the authors moved on to the issue of the boundaries of future Armenia. The idea of establishing a "Larger Armenia" (six Western Armenian vilayets, except for the southern and western provinces, Cilicia, Trebizond) was rejected the first with justification that in 1914 and even before 1894 Armenians were a minority in the specified area, never exceeding the $25 \% .{ }^{77}$ "Even if we take into account the one million Armenians who were killed ${ }^{78}$ and assuming that it would be possible to gather all of them in this area, still the Armenians would make up only about the third of the population," added the authors of the report. ${ }^{79}$

The report maintained the creation of a so called "Smaller Armenia" to which only a portion of the territories geographically belonging to the Armenian Plateau would be appended from the Ottoman Empire with an outlet to the Black Sea, roughly equal to the area occupied by Russian troops during the Great War. In justification of their viewpoint, again demography was referred to as the first argument: "The Turks and Kurds would not be able to justifiably complain about such an area, as this is historical Armenia, and also because, if it were possible to recover the one million dead Armenians and bring them to that area, the Armenians would make up half of the population. "80

In the Estimates of the Population of an Armenian State subsection of the report there were several tables on the number of the population of the supposed territory of the future Armenian state. The first of them reflected the 1914 situation. The statistics were given for three contingent regions "Larger Turkish Armenia," approximately covering the six vilayets, except for the southern and western provinces, the eastern portion of Trebizond vilayet and Cilicia (Adana vilayet and Marash sanjak), "Smaller Turkish Armenia," approximately corresponding to the area occupied by the Russian troops in 1917, which is the eastern portion of Trebizond vilayet, Van vilayet without Hakkiari, the whole of Erzeroum vilayet and Bitlis vilayet without Sgherd, and "differential area", the area left after separation/ subtraction of the "Smaller Armenia" from the "Larger Armenia" - Kharput vilayet, eastern regions of Sivas vilayet and Cilicia (Adana vilayet and Marash sanjak) (see Table 3).

Table 3. Population of Western Armenia according to King-Crane Mission Report

\begin{tabular}{|c|c|c|c|c|c|c|c|c|c|}
\hline & $\%$ & Muslims & $\%$ & $\begin{array}{c}\text { Arme- } \\
\text { nians }\end{array}$ & $\%$ & Greeks & $\%$ & Other & Total \\
\hline Larger Turkish Armenia & 71 & $3,073,000$ & $21^{1 / 2}$ & 933,000 & $6^{1 / 2}$ & 289,000 & 1 & 34,000 & $4,329,000$ \\
\hline
\end{tabular}

77 Ibid., 821.

78 The authors of the report mean the number of Armenians who feel victim to 1894-1896 Hamidian massacres and the Armenian Genocide.

79 Ibid.

80 Ibid., 822. 


\begin{tabular}{|c|c|c|c|c|c|c|c|c|c|}
\hline Differential area & 73 & $1,697,000$ & 20 & 461,000 & 6 & 136,000 & 1 & 18,000 & $2,312,000$ \\
\hline Smaller Turkish Armenia & 68 & $1,376,000$ & $23^{1 / 2}$ & 472,000 & $7^{1 / 2}$ & 153,000 & 1 & 16,000 & $2,017,000$ \\
\hline
\end{tabular}

The authors mentioned in the annotations on the report that the above table was estimated from the statistics prepared by Drs Magie and Westermann. Of importance is also the observation of the authors of the report that Magie's figures may underestimate the Armenians in some regions. ${ }^{81}$ They also found that it would not be possible to be definite about the number of various ethnic elements in Turkey until a scientific ethnological survey had been carried out under disinterested control. ${ }^{82}$ It should be noted that similar statements regarding Western Armenia demographics were being made by Western diplomats and researchers since 1878 in the earlier stages of the Armenian Question as well. ${ }^{83}$

The Harbord Military Mission Report stated that "conservative" estimates place the number of Armenians over 1,500,000 in Asiatic Turkey in 1914 (without Constantinople and Adrianople vilayet), "though some make it higher." ${ }^{84}$ It was noted that official reports of the Turkish Government showed that in 1915 around 1,100,000 Armenians were deported. Upon describing briefly the progression of the anti-Armenian actions of the Turkish authorities, the report stated that the dead from this "wholesale attempt" on the race are variously estimated from 500,000 to over one million, "the usual figure being about 800,000."

In the opinion of the authors of the report, "...even before the war the Armenians were far from being a majority in the region claimed as Turkish Armenia, excepting in a few places." "To-day we doubt if they would be in majority in a single community even when the last survivors of the massacres and deportations have returned to the soil, though, - the report went on, - the great losses of Turkish population to some extent offset the difference brought about by slaughter. " 86

Of certain interest is the authors' estimate, as of 1919, of Armenians living in Turkish Armenia (western regions of Sivas vilayet, including the province of Shabin-Karahisar, Cilicia (Adana vilayet, Marash sanjak and Aintab district), Kharput vilayet, the northern portion of Diarbekir vilayet, the vilayet of Bitlis without Sgherd province, Van vilayet (without Hakkiari province), Erzeroum and Trebizond vilayets) and the number of Western Armenian refugees in Transcaucasus: "We estimate that there are probably 270,000 Armenians today in Turkish Armenia. Some 75,000 have been repatriated from the Syrian and Mesopotamian side, others are slowly returning from other regions, and some from one cause or

81 Ibid., 825.

82 Ibid.

83 See about that in detail Tatoyan, The Question of the Number of the Western Armenians in 1878-1914, 121165.

84 Conditions in the Near East. Report of the American military mission to Armenia, by Maj. Gen. James G. Harbord, U.S. Army. (Appendix only) (Washington: Govt. printing office, 1920), 7.

85 Ibid.

86 Ibid. 
another remained in the country (the last group includes the Islamized Armenians - R.T.). There are in the Transcaucasus probably 300,000 refugees from Turkish Armenia, and some thousands more in other lands, for they have drifted to all parts of Near East." 87

At the end of the report statistical data was presented on the population and resources of "European Turkey, Asia Minor and Transcaucasus" in the form of tables; of interest are, from the viewpoint of the above issue, the data on the total number of the pre- and post-war population of "Turkish Armenia," ${ }^{88}$ which we insert in Table 4.

Table 4. Population of Western Armenia according to Harbord Military Mission Report

\begin{tabular}{|c|c|c|c|c|c|}
\hline \multicolumn{6}{|c|}{ Turkish Armenia } \\
\hline \multirow[b]{2}{*}{$\begin{array}{l}\text { Vilayet } \\
\text { Province Sanjak/district }\end{array}$} & \multirow[b]{2}{*}{$\begin{array}{l}\text { Area, square } \\
\text { km }\end{array}$} & \multicolumn{2}{|c|}{ Present } & \multicolumn{2}{|c|}{ Pre-war } \\
\hline & & $\begin{array}{l}\text { Population in } \\
\text { thousands }\end{array}$ & $\begin{array}{l}\text { Density per } \\
\text { square kilo- } \\
\text { metre }\end{array}$ & & $\begin{array}{c}\text { Densi- } \\
\text { ty per } \\
\text { square } \\
\text { kilome- } \\
\text { tre }\end{array}$ \\
\hline $\begin{array}{l}\text { Eastern Sivas (including } \\
\text { Shabin-Karahisar province) }\end{array}$ & 38.6 & 319 & 8 & 507 & 14 \\
\hline Adana vilayet & 25.1 & 193 & 8 & 320 & 13 \\
\hline $\begin{array}{l}\text { Marash province and Aintab } \\
\text { Sanjak }\end{array}$ & 16.0 & 102 & 6 & 170 & 11 \\
\hline Kharput vilayet & 32.9 & 282 & 9 & 450 & 14 \\
\hline $\begin{array}{l}\text { Diarbekir vilayet (Northern } \\
\text { portion) }\end{array}$ & 16.1 & 186 & 12 & 296 & 18 \\
\hline $\begin{array}{l}\text { Bitlis vilayet (without Sgherd } \\
\text { province) }\end{array}$ & 19.7 & 229 & 12 & 382 & 19 \\
\hline $\begin{array}{l}\text { Van vilayet (without Hakkiari } \\
\text { province) }\end{array}$ & 21.0 & 204 & 10 & 350 & 17 \\
\hline Erzeroum vilayet & 49.7 & 398 & 8 & 630 & 13 \\
\hline Trebizond vilayet & 32.5 & 685 & 21 & 1,000 & 31 \\
\hline Total & 249.8 & 2,598 & 10 & 4,105 & 16.4 \\
\hline
\end{tabular}

87 Ibid., 8 .

88 Ibid., 41-42. 
A summary document in the sense of taking in the US official standpoint on the number of Western Armenians, could be considered the report attached to the US president Woodrow Wilson's arbitral award on Armenia-Turkey border (22 November 1920) prepared by a special commission set up for that purpose (see Full Report of the Committee upon the Arbitration of the Boundary between Turkey and Armenia). ${ }^{89}$ According to the authors of the report, for them, underlying the determination of the boundary between Armenia and Turkey, were three guiding considerations, one of which was ethnography (the other two being geography and economy)..$^{90}$ The report said that the study of ethnic elements that constituted the population of Western Armenia was rather a shady business ("greatly beclouded") conditioned by lack of reliable pre-war statistics on Western Armenian vilayets, the deportations and massacres of Armenians, the losses of the Turkish and Kurdish population. ${ }^{91}$

In their estimations of the number of the population of Western Armenia on the eve of the Armenian Genocide the authors of the report also relied on the data of the above The Population of Asiatic Turkey study of Professor Magie circulated during the Paris Peace Conference by the American delegation. Based on the very data extracted from the abovementioned report justified was the exclusion of Hakkiari province of Van vilayet and Sgherd sanjak of Bitlis vilayet from the boundaries of the future Armenia (it should be noted that the Armenian side never claimed the mentioned regions). Noteworthy is the statistics for the mentioned provinces in the report, which in terms of the number of the Armenians came close to or even exceeded the figures of the Armenian Patriarchate ${ }^{92}$ (see Table 5).

Table 5. Population of Hakkiari and Sgherd according to Magie

\begin{tabular}{|c|c|c|c|c|}
\hline & Turks & Kurds & Armenians & Nestorians (Assyrians) \\
\hline \multirow{2}{*}{ Hakkiari } & 10,000 & 130,000 & 10,000 & 85,000 \\
& $(4.15 \%)$ & $(54.4 \%)$ & $(4.15 \%)^{93}$ & $(35.9 \%)$ \\
\hline \multirow{2}{*}{ Sgherd } & 66,000 & & 26,000 & - \\
& $(65.3 \%)$ & & $(25.7 \%)^{94}$ & \\
\hline
\end{tabular}

If leaving Sgherd and Hakkiari provinces outside the boundaries of Armenia the authors explained with ethnographic considerations, appending a portion of the vilayet of Trebizond to Armenia was conditioned by "absolute and decisive" economic considerations, i.e. the imperative of Armenia having an outlet to the sea. ${ }^{95}$

89 Arbitral Award of the President of the United States of America Woodrow Wilson: Full Report of the Committee upon the Arbitration of the Boundary Between Turkey and Armenia. Washington, November 22nd, 1920, prepared with an Introduction by Ara Papian (Yerevan: Asoghik, 2011).

90 Ibid., 15.

91 Ibid., 16.

92 Ibid., 18.

93 According to the Armenian Patriarchate 1912 data - 12,000 (see Teodik, Almanac, 262).

94 According to the Armenian Patriarchate 1912 data 18,000 (see Teodik, Almanac, 262).

95 Ibid. 


\section{Great Britain Experts on the Issue of the Number of Western Armenians}

In the spring of 1917 the British Foreign Office, in preparations for the Peace Conference, set up a special section which was supposed to provide information to the British delegates to the Conference about geography, economy, history, social, religious and political aspects of various countries in question. One of the numerous reports prepared by the section under the title of Armenia and Kurdistan related to Western Armenia. ${ }^{96}$ The Population subsection of the report contained statistical data on the number of the population of Western Armenia on the eve of the Armenian Genocide.

The authors of the report first noted that the data of interest had been extracted from various pre-war statistics and should be perceived as approximate, regardless of the source. Then the report gave the total number of the population of Armenia and "Kurdistan" vilayets, according to the Turkish statistics, followed by the 1912 statistics of the Armenian Patriarchate on the six Armenian vilayets of Turkey (see Table 1). Separately it presented the statistics on the Armenian population of Cilicia by dioceses compiled and published by the Armenian Catholicosate of Sis in 1913, according to which there were 318,416 Armenians living on the territory of Cilicia at that time. ${ }^{97}$

Quite noteworthy is the following observation of the authors of the report: "It is probable that the figures for the Armenians are too low rather than too high, since the existence of a capitation tax tended to make the Armenians conceal rather than exaggerate their own numbers." 98 This argument was repeatedly stated in the past by all unbiased researchers familiar with the issue.

The British Foreign Office did not confine itself only to collecting statistical data on the population of Western Armenia and other territories of the Ottoman Empire on the eve of the Great War from various sources, but also made an attempt to compile its own statistics based on them. A sample of such statistics is the statistical table prepared by the Geographical Department of the British Foreign Office. As data sources for the table served the 1914 official Ottoman statistics, data provided by Greek and Armenian church sources and particularly the Population of Asiatic Turkey at the Outbreak of the War report prepared by Professor D. Magie, the expert of the Western Asia section of the American expert group already mentioned. ${ }^{99}$ According to the data in the document, there were 1,604,000 Armenians (for the distribution of Armenians and Muslims by Western Armenian vilayets see Tables 6 and 7) living in the territory of the Ottoman Empire in 1914, except for the capital Constantinople. ${ }^{100}$

\footnotetext{
96 Armenia and Kurdistan (London: H.M. Stationery Office, 1920).

97 Ibid., 7.

98 Ibid., 6.

99 Zamir, "Population Statistics of the Ottoman Empire," 87.

100 Ibid., 106.
} 


\section{Comparison and Analysis of the Ottoman, Armenian and Western (An- glo-American) Statistical Data}

The collation and comparison of the Ottoman, Armenian and Western (Anglo-American) statistical data for the Western Armenian territory presented to the Paris Peace Conference (see Table 6) showed that in case of the Armenian population in the area in question, the Armenian data was by about $83 \%$ higher than the Ottoman and $18 \%$ higher than the Anglo-American experts' data. In their turn, the Anglo-American expert data on the Western Armenians were by about 50\% higher than the Ottoman and about $18 \%$ lower than the Armenian data; in case of the Muslim population of Western Armenia (see Table 7) the Ottoman data was higher by about $188 \%$ than the Armenian and about $18 \%$ than the Anglo-American experts' data. This came to prove that the diplomats and experts of the US and Great Britain, within the framework of post-war regulation, in their statements about and appraisals of the demographic composition of Western Armenia were either relying on the Armenian data, or making their own calculations. In case of the number of the Western Armenians, the authenticity of the Ottoman official statistics was rejected and preference was given to the Armenian sources. In case of the Muslim population, the Anglo-American experts were making their calculations based on the data of the Ottoman government, as well as those of Vital Cuinet and from Western sources. The Anglo-American experts' statistics for Western Armenia also contained separate data for major Muslim ethnic groups, particularly, Turks and Kurds, living there, which Ottoman official statistics never provided.

At the same time, the United States and Great Britain, while acknowledging the falsehood of the Ottoman statistics on the Western Armenians and the reliability of figures of Armenian origin, frequently were accentuating the argument of the Western Armenians yielding to the Muslims in percentage even on the eve of the Armenian Genocide in order to curb Armenian claims in the context of making peace with a defeated Turkish state. ${ }^{101}$

In conclusion, we believe that the figures standing for the number of the Ottoman Armenians from the Ottoman government, Western authors, and even the Armenian Patriarchate of Constantinople are undercountings to a lesser or greater extent. This is evidenced by available Armenian sources referring to the eve of the Armenian Genocide (data on the registration and survey of the Armenian refugees, information provided by survivors of the Armenian Genocide about their native localities, etc.) in many cases independently providing much higher numbers for the Armenian population of a given locality and administrative unit than those of the three abovementioned sources. ${ }^{102}$ At the same time, when critically ap-

\footnotetext{
101 Interestingly, later, after the victories of the Kemalists, during the Lausanne Conference of 1922 November convened to review the treaty of Sevres and make peace with a new, Kemalist Turkey, the British diplomacy was employing the opposite tactic, this time to extort concessions from the Turks. Thus, during one of the sessions, the Head of the British delegation foreign secretary Lord Curzon addressed a series of rhetorical questions to the Head of the Turkish delegation Ismet Inonu, "How did it happen that the number of Armenians previously inhabiting in Asia Minor decreased from 3,000,000 to 130,000? Did they commit suicide or did they leave on their own? Why have hundreds of thousand Armenians become refugees taking refuge in all countries of the world? Why is the Armenian Question one of the biggest shames in the world?" Akaby Nassibian, Britain and the Armenian Question, 1915-1923 (New York: St. Martin's Press, 1984), 145.

102 For more details about it see Tatoyan, The Question of the Number of the Western Armenians in 1878-1914, $100-114$
} 
proached and collated with the materials of other sources, the quite rich, though contradictory, statistical material made known due to the raising of the Armenian question in 19191920 could be used to study the complicated issue of the number of Western Armenians on the eve of the Armenian Genocide and particularly, verify the number of the Armenians by the separate administrative units of the Ottoman Empire.

Table 6. Armenian Population of Western Armenia, Trebizond and Cilicia (Adana and Marash) Vilayets and the Other Parts of the Ottoman Empire on the Eve of the Armenian Genocide according to Different Statistical Data Presented to the Paris Peace Conference

\begin{tabular}{|c|c|c|c|}
\hline Administrative unit & Ottoman data & $\begin{array}{l}\text { Armenian Delega- } \\
\text { tion }\end{array}$ & $\begin{array}{c}\text { Inquiry expert group (USA) } \\
\text { Geographical Department of } \\
\text { the Foreign Office of Great } \\
\text { Britain }\end{array}$ \\
\hline \multicolumn{4}{|l|}{ Western Armenia } \\
\hline Van vilayet & \multicolumn{2}{|c|}{$\begin{array}{r}67,792 \\
197,000\end{array}$} & 190,000 \\
\hline Bitlis vilayet & 119,132 & 198,000 & 185,000 \\
\hline Erzeroum vilayet & 136,618 & 215,000 & 205,000 \\
\hline Diarbekir vilayet & 73,226 & 124,000 & 82,000 \\
\hline Kharput vilayet & 87,864 & 204,000 & 130,000 \\
\hline Sivas vilayet & 151,674 & 225,000 & 200,000 \\
\hline Total six vilayets & 636,306 & $1,163,000$ & 992,000 \\
\hline Trebizond vilayet & 40,237 & 65,000 & 33,000 \\
\hline $\begin{array}{l}\text { Total (including Trebizond } \\
\text { vilayet) }\end{array}$ & 676,543 & $1,228,000$ & $1,025,000$ \\
\hline \multicolumn{4}{|l|}{ Cilicia } \\
\hline Adana vilayet & 57,686 & 118,000 & 75,000 \\
\hline Marash province & 38,433 & $69,000^{103}$ & 55,000 \\
\hline Total & 96,119 & 187,000 & 130,000 \\
\hline Total (including Cilicia) & 772,662 & $1,415,000$ & $1,155,000$ \\
\hline $\begin{array}{l}\text { Other parts of the Ottoman Em- } \\
\text { pire }\end{array}$ & 522,189 & 611,000 & 449,000 \\
\hline Grand total & $1,294,851$ & $2,026,000$ & $1,604,000$ \\
\hline
\end{tabular}

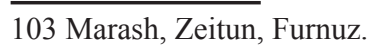


Table 7. "Muslim" Population of Western Armenia and Cilicia (Adana and Marash) Vilayets on the Eve of the Armenian Genocide according to Different Statistical Data Presented to the Paris Peace Conference

\begin{tabular}{|c|c|c|c|}
\hline Administrative unit & $\begin{array}{c}\text { Ottoman } \\
\text { Government }\end{array}$ & $\begin{array}{l}\text { Armenian Dele- } \\
\text { gation }^{104}\end{array}$ & $\begin{array}{l}\text { Inquiry expert group (USA) -Geograph- } \\
\text { ical Department of the Foreign Office of } \\
\text { Great Britain }\end{array}$ \\
\hline \multicolumn{4}{|l|}{ Western Armenia } \\
\hline Van vilayet & 179,380 & $122,000^{105}$ & $259,000^{106}$ \\
\hline Bitlis vilayet & 309,999 & $127,000^{107}$ & $261,000^{108}$ \\
\hline Erzeroum vilayet & 673,297 & 345,000 & $540,000^{109}$ \\
\hline Diarbekir vilayet & 492,101 & $100,000^{110}$ & $400,000^{111}$ \\
\hline Kharput vilayet & 446,379 & $197,000^{112}$ & $280,000^{113}$ \\
\hline Sivas vilayet & 939,735 & $287,000^{114}$ & 977,000 \\
\hline Total six vilayets & $3,040,891$ & $1,178,000$ & $2,717,000$ \\
\hline Trebizond vilayet & $1,187,078$ & $301,000^{115}$ & 848,000 \\
\hline $\begin{array}{l}\text { Total six vilayets and Trebi- } \\
\text { zond vilayet }\end{array}$ & $4,227,969$ & $1,479,000$ & $3,565,000$ \\
\hline \multicolumn{4}{|l|}{ Cilicia } \\
\hline Adana vilayet & 341,903 & - & 290,000 \\
\hline Marash province & 152,645 & - & $146,000^{116}$ \\
\hline Total Cilicia & 494,548 & $156,000^{117}$ & 436,000 \\
\hline Grand total & $4,722,517$ & $1,635,000^{118}$ & $4,001,000$ \\
\hline
\end{tabular}

104 Except for Kizilbashis, Zazas, Chariklies and Yezidies.

105 Without Hakkiari sanjak.

106 Including 57,000 Turks and 202,000 Kurds.

107 Without Sgherd sanjak.

108 Including 60,000 Turks and 201,000 Kurds.

109 Including 335,000 Turks and 205,000 Kurds.

110 Without Mardin sanjak, Bsherik kaza and Severek.

111 Including 100,000 Turks, 230,000 Kurds and 70,000 Muslim Arabs.

112 Without Malatya province.

113 Including 250,000 Turks and 230,000 Kurds.

114 Only Sebastia and Shabin-Karahisar provinces.

115 Except for Samsun sanjak.

116 Including 82,000 Turks, 56,000 Kurds and 8,000 Muslim Arabs.

117 Marash, Kozan and Djebel Bereket sanjaks.

118 The grand total number according to the data in the memorandum submitted to the Paris Peace Conference by Armenian Delegation (see The Armenian Question before the Peace Conference, 32). 